\title{
Re-irradiation for Recurrent Primary Brain Tumors
}

\author{
CARSTEN NIEDER ${ }^{1,2}$, NICOLAUS H. ANDRATSCHKE ${ }^{3}$ and ANCA L. GROSU ${ }^{4}$ \\ ${ }^{1}$ Department of Oncology and Palliative Medicine, Nordland Hospital, Bod $\phi$, Norway; \\ ${ }^{2}$ Department of Clinical Medicine, Faculty of Health Sciences, \\ UiT - The Arctic University of Norway, Troms $\phi$, Norway; \\ ${ }^{3}$ Department of Radiation Oncology, University Hospital Zurich, Zurich, Switzerland; \\ ${ }^{4}$ Department of Radiation Oncology, University Hospital Freiburg, Freiburg, Germany
}

\begin{abstract}
Background: Historically, radiation oncologists have been cautious about re-irradiating brain tumors because of concerns about the risks of late central nervous system (CNS) toxicity, especially radionecrosis, that may occur several months to years following treatment. Today there are still limited prospective data addressing this approach. Materials and Methods: Systematic review of published trials reporting clinical results after re-irradiation of patients with different types of brain tumors was performed. Results: Data mainly related to glioblastoma, anaplastic glioma, medulloblastoma, ependymoma and meningioma have been published. Randomized studies are scarce. As in first-line scenarios, efficacy of radiotherapy is influenced by histology. Based on the reported outcomes, preliminary recommendations for doselfractionation regimens can be given. Conclusion: Re-irradiation of brain tumors is increasingly considered as our understanding of brain tolerance to radiation evolves and developments in radiation technology and imaging make highly accurate targeting of recurrent tumors possible. With developments in systemic therapy, further exploration of the role of re-irradiation on its own or in combination with novel agents is needed.
\end{abstract}

The current postoperative standard treatment for glioblastoma (GBM) is radiotherapy with concurrent and adjuvant temozolomide. With this approach, 5-year overall survival is $9.8 \%$ compared to $1.9 \%$ with radiotherapy alone

This article is freely accessible online.

Correspondence to: Carsten Nieder, MD, Department of Oncology and Palliative Medicine, Nordland Hospital, 8092 Bod $\varnothing$, Norway. Tel: +47 75578449, Fax: +47 75534975, e-mail: carsten.nieder@nlsh.no

Key Words: Brain tumor, glioma, glioblastoma, radiotherapy, reirradiation, salvage treatment, review.
(1). Recent data suggest that maintenance therapy with tumor-treating fields in addition to temozolomide improves survival (2). Efforts have been made to standardize the target volume definition (3). Nevertheless, despite an increase in survival rates, the majority of patients progress within 10-15 months. Also for anaplastic astrocytomas and low-grade gliomas, radiotherapy remains a common first-line treatment. In these tumors, the time to progression is longer but the majority ultimately also recurs. Salvage therapy is indicated in the majority of recurrent gliomas and most patients receive systemic therapy and/or surgery at relapse.

Historically, many radiation oncologists have been cautious about re-irradiating brain tumors because of concerns about the risks of toxicity, e.g., radionecrosis. Reirradiation for brain tumors is now more frequently used because developments in radiation technology and imaging allow for highly accurate targeting of biologically relevant tumor volumes and, furthermore, several studies have demonstrated the feasibility of this treatment paradigm. This review summarizes radiobiological principles behind reirradiation of different types of brain tumors and discusses the current evidence from clinical studies.

\section{Overview of Treatment Options for Recurrent Gliomas}

External-beam radiotherapy is an integral part of treatment of low- and high-grade gliomas. At relapse, treatment options have included further surgical resection, systemic therapy, including prospective trials of new agents, and re-irradiation. Currently, however, there is no agreed standard of care.

The extent of surgical resection at relapse is frequently limited by the infiltrative nature of these tumors and the need to avoid severe neurological deficits from further surgical intervention. For those patients able to undergo re-resection, the use of impregnated carmustine wafers in the surgical 
cavity improved median survival by 8 weeks in a placebocontrolled study (4). It has also been shown that the extent of repeat resection was associated with survival (5-7). Patients with complete resection of gadolinium-enhancing tumor at first recurrence did benefit from reoperation, in contrast to those with incomplete resection (7).

There are few randomized controlled clinical trials in the treatment of recurrent glioma. Wong et al. (8) published a review on outcomes and prognostic factors for recurrent gliomas treated within phase II trials. From the eight studies reviewed the progression-free survival at 6 months was $21 \%$, median progression-free survival was 10 weeks and median overall survival was 30 weeks. GBM patients had significantly poorer outcomes than those with anaplastic astrocytoma. Results were also worse for those with more than two prior operations or two prior chemotherapy regimes. With investigator-declared non-efficacious regimens pooled from 16 studies, progression-free survival at 6 months was $9 \%$ and overall survival at 1 year $14 \%$ (9).

Huncharek and Muscat (10) published a systematic review of outcomes from treatment of high-grade gliomas at relapse. They analyzed 40 trials (36 non-randomized controlled trials and 4 randomized controlled trials). Thirty-two of the trials addressed the outcome after chemotherapy and only seven were radiotherapy trials. Chemotherapy with nitrosoureas was associated with significantly prolonged time to tumor progression compared to all other drugs (26.9 weeks). The nitrosoureas and platinums were the most active drugs with regard to overall survival (32 weeks). Average median survival for patients treated with radiation was 44.7 weeks but selection bias prevented comparison with chemotherapy studies.

The use of temozolomide at recurrence has been investigated in several phase II studies with different dose regimes and seems to be associated with improved progression-free and overall survival (11-13). New information on biomarker selection for patients who are likely to be sensitive to temozolomide (MGMT promoter methylation) may alter the proportion of patients who are deemed suitable for this treatment (14).

Angiogenesis inhibition with bevacizumab (a humanized monoclonal antibody against vascular endothelial growth factor (VEGF)) has been introduced in the clinic in several countries but there is still controversy about the role of this agent and whether it should be combined with chemotherapy $(15,16)$. In the BELOB phase 2 trial, 51 patients were assigned to receive bevacizumab alone, 47 to receive lomustine alone and 47 to receive bevacizumab plus lomustine (16). Nine-month overall survival was $43 \%$ (95\% confidence interval $(\mathrm{CI})=29-57)$ in the lomustine group, 38\% $(\mathrm{CI}=25-51)$ in the bevacizumab group, $59 \%(\mathrm{CI}=43-72)$ in the bevacizumab and lomustine $90 \mathrm{mg} / \mathrm{m}^{2}$ group, 87\% (CI=39-98) in the bevacizumab and lomustine $110 \mathrm{mg} / \mathrm{m}^{2}$ group and $63 \%$ $(\mathrm{CI}=49-75)$ for the combined bevacizumab and lomustine groups. After the reduction in lomustine dose in the combination group, the combined treatment was welltolerated. The combination of bevacizumab and lomustine met pre-specified criteria for assessment of this treatment in a phase III trial, which has been published as abstract and did not show a survival advantage for combined therapy (17).

Retrospective data suggest that multimodal treatment with repeat surgery or re-irradiation and chemotherapy is better than chemotherapy alone (18). Other data suggest that no significant difference between re-irradiation and surgery exists (19). In this study, both local approaches were followed by dendritic cell vaccination.

\section{The Biology of Late Central Nervous System (CNS) Toxicity}

The biology of late CNS toxicity is thought to be a complex dynamic process involving many cell types and interactions with no known effective means of prevention or treatment (20-22). Available animal data come mainly from studies investigating spinal cord tolerance to irradiation $(23,24)$. The pathogenesis of radiation toxicity and recovery potential in the brain is assumed to be similar to the spinal cord and the structures of the CNS are assumed to have a low $\alpha / \beta$ ratio (25). Therefore, fractionation of the total radiation dose is a means to limit the risk of toxicity. Pre-clinical data suggest that there is significant recovery following irradiation. For example, pigs receiving spinal radiosurgery one year after an initial series of fractionated radiotherapy (30 Gy in 10 fractions of $3 \mathrm{~Gy}$ ) tolerated reirradiation without significantly increased risk of motor deficits compared to controls who received only one radiosurgery treatment (26). Overall, the toxicity resulting from re-treatment depends on dose, volume and time between exposures. A conservative estimate is that up to $50 \%$ recovery may occur within 1-2 years post initial treatment if doses below full tolerance have been given at first exposure. In animal models of spinal cord re-irradiation, no microscopic lesions were seen with a cumulative dose less than 110 Gy (27). Other animal experiments with histological and imaging assessment after thalamic radiosurgery showed that delayed effects also involved the white matter beyond the target (28). The exact contributions of soluble mediators and other microenvironmental signals on the chronic process of radiation-induced changes, both within and outside the high-dose region, are still under investigation $(29,30)$. With the advent of tumor-treating fields, additional experiments investigating their influence on the dynamics of radiation-induced changes appear warranted.

\section{Prognostic Factors for Survival}

Carson et al. published an evaluation on prognostic factors for patients with recurrent high-grade gliomas based on 10 prospective phase I and II trials by using a recursive 
partitioning analysis to define seven prognostic groups (31). Relevant prognostic factors included performance status, initial histology, age and corticosteroid use. They concluded that patients with recurrent gliomas entering clinical trials have widely variable outcomes, many of which depend on initial clinical characteristics and baseline demographic variables. These may be applicable in selecting patients for re-irradiation.

Combs et al. used their database of fractionated stereotactic radiotherapy with 233 patients (32). Primary histology included GBM $(\mathrm{n}=89 ; 38 \%)$, WHO grade III gliomas $(n=52 ; 22 \%)$ and low-grade glioma $(n=92 ; 40 \%)$. Re-irradiation was applied with a median dose of $36 \mathrm{~Gy}$ in 2-Gy single fractions. Median survival was 8 months for GBM, 20 months for anaplastic gliomas and 24 months for recurrent low-grade tumors. The strongest prognostic factors significantly impacting survival after re-irradiation were histology $(p<0.0001)$ and age $(<50 v s . \geq 50, p<0.0001)$ at diagnosis and the time between initial radiotherapy and reirradiation $\leq 12 v s .>12$ months $(p<0.0001)$. They generated a four-class prognostic score to distinguish patients with excellent ( 0 points), good ( 1 point $)$, moderate ( 2 points) and poor (3-4 points) survival after re-irradiation. However, first attempts towards external validation of this score were not successful $(33,34)$. Reasons might include the frequent use of bevacizumab in one of the validation studies or their limited size and other methodological problems. A larger validation study was successful (35).

Müller et al. defined three prognostic classes based on histology, age and performance status (19). Regardless of local treatment approach (re-irradiation or surgery, each followed by dendritic cell vaccination), the 1-year survival rate was approximately $70 \%$ in the best prognostic group.

\section{Evidence for Re-irradiation}

There are over 50 clinical studies in the literature on reirradiation of gliomas. The majority of these studies is retrospective and uses a variety of techniques, including brachytherapy, fractionated stereotactic radiotherapy, radiosurgery and conformal or intensity-modulated radiotherapy with or without new systemic agents (Table I). Besides differing techniques, the published data include a wide range of doses, emphasizing on the fact that no standard approach exists (63). Inter-study comparison is difficult because the literature is confounded by a lack of standardized recording of all radiotherapy and outcome variables. In addition, some patients were treated at first and others at second or third progression.

Although the biology of re-irradiation remains to be fully understood, there is now a large body of clinical and animal data that can guide recommendations. Mayer and Sminia identified and analyzed 21 re-irradiation studies and reviewed the available clinical data on re-irradiation of gliomas with respect to tolerance of the normal brain (64). They discussed that the incidence of toxicity, including radionecrosis, may be under-reported since only symptomatic necrosis is likely to be recorded. According to their analysis, the major factor contributing to necrosis was the total dose received. There was no correlation between time to re-irradiation and the development of necrosis, although the minimum time interval between treatments in this analysis was 3 months. They concluded that the incidence of necrosis did not increase significantly until the total cumulative dose was $100 \mathrm{~Gy}$.

\section{Target Definition}

Magnetic resonance imaging (MRI) plus gadolinium remains the gold standard imaging modality for target definition for gliomas (3). The problems are that, following surgery or radiotherapy, the signal change based on gadolinium enhancement can be non-specific, making accurate target definition a challenge. Additionally, in patients treated with bevacizumab, the true extent of recurrent or progressing tumor may be obscured and underestimated. Most gliomas recur close to the margin of the original lesion and this is often where non-specific signal changes due to prior treatment are also apparent (65).

To optimise the outcome of radiotherapy, accurate target definition is of paramount importance. In this context, biological imaging may improve the definition of the relevant target (66-69). Miwa et al. reported a small study of 11C-methionine positron emission tomography (METPET)/CT/MRI fusion (70). Twenty-one patients with recurrent GBM received hypofractionated stereotactic IMRT planned by MET-PET/CT/MRI. The region of increased amino acid tracer uptake on MET-PET was defined as the gross tumor volume. The planning target volume encompassed the GTV by a 3-mm margin. Median survival was 11 months. In 42 patients with brain tumors (29 gliomas and 13 metastases from extracranial primary tumors) pretreated with surgery and/or radiation therapy, FET-PET and MET-PET were performed on the same day. Standardized uptake value (SUV) for normal and tumor tissue, GTV and sensitivity $(100 \%)$ and specificity $(91 \%)$ were similar for both tracers (71). Especially after irradiation, FET-PET and MET-PET were able to distinguish treatment-related changes from tumor recurrence. Currently, there is no standard recommendation on what imaging modality has to be incorporated and what specific margins should be applied. The minimal consensus may be summarized as to confine GTV definition to gadolinium-enhancing regions. The GLIAA (NOA 10) study (NCT01252459), an ongoing multicentre, prospective randomized, phase II clinical trial, evaluates the impact of FET-PET versus T1Gd-MRI target volume delineation on the outcome of patients with recurrent 
Table I. Summary of relatively large re-irradiation studies for patients with recurrent gliomas.

\begin{tabular}{|c|c|c|c|}
\hline Authors & Case number & Technique/dose & Median surviva \\
\hline \multicolumn{4}{|l|}{ Brachytherapy } \\
\hline Scharfen et al. 1992 (36) & $66 \mathrm{GBM}$ & Brachytherapy I-125 64.4 Gy & 11.3 months \\
\hline Sneed et al. 1997 (37) & 66 GBM & Brachytherapy I-125 64.4 Gy & 11.7 months \\
\hline & 45 WHO III & & 12.3 months \\
\hline Simon et al. 2002 (38) & 42 GBM & Brachytherapy Ir-192 40-60 Gy & 50 weeks \\
\hline Gabayan et al. 2006 (39) & $\begin{array}{l}81 \text { GBM } \\
14 \text { WHO III }\end{array}$ & Gliasite brachytherapy $60 \mathrm{~Gy}$ at $10 \mathrm{~mm}$ & $\begin{array}{l}35.9 \text { weeks } \\
43.6 \text { weeks }\end{array}$ \\
\hline Tselis et al. 2007 (40) & 84 GBM & Brachytherapy Ir-192 40 Gy & 37 weeks \\
\hline Fabrini et al. 2009 (41) & $\begin{array}{l}18 \mathrm{GBM} \\
3 \text { WHO III }\end{array}$ & HDR brachytherapy $18 \mathrm{~Gy}$ & 8.0 months \\
\hline Kickingereder et al. 2014 (42) & $98 \mathrm{GBM}$ & Brachytherapy I-125 60 Gy & 10.4 months \\
\hline Schwartz et al. 2015 (43) & $\begin{array}{l}40 \mathrm{GBM} \\
28 \mathrm{WHO} \text { III }\end{array}$ & Brachytherapy I-125 50 Gy & 13.4 months \\
\hline \multicolumn{4}{|l|}{ Stereotactic radiosurgery } \\
\hline Shrieve et al. 1995 (44) & $86 \mathrm{GBM}$ & Stereotactic radiosurgery 13 Gy & 10.5 months \\
\hline Cho et al. 1999 (45) & 46 GBM & Stereotactic radiosurgery $17 \mathrm{~Gy}$ & 11.0 months \\
\hline Combs et al. 2005 (46) & $32 \mathrm{GBM}$ & $\begin{array}{l}\text { Stereotactic radiosurgery } \\
\text { Median } 15 \text { Gy (10-20 Gy) }\end{array}$ & 10.0 months \\
\hline Combs et al. 2005 (47) & $\begin{array}{l}54 \text { GBM } \\
39 \text { WHO III }\end{array}$ & $\begin{array}{c}\text { Stereotactic radiotherapy } \\
36 \text { Gy }(15-62 \text { Gy }) \\
5 \times 2 \text { Gy conventional fractionation }\end{array}$ & $\begin{array}{l}8.0 \text { months } \\
16.0 \text { months }\end{array}$ \\
\hline Kong et al. 2008 (48) & $\begin{array}{l}65 \text { GBM } \\
49 \text { WHO III }\end{array}$ & Stereotactic radiosurgery 16 Gy & $\begin{array}{l}13.0 \text { months } \\
26.0 \text { months }\end{array}$ \\
\hline Patel et al. 2009 (49) & $36 \mathrm{GBM}$ & $\begin{array}{c}\text { Stereotactic radiosurgery } 18 \mathrm{~Gy} \\
\text { Fractionated stereotactic radiotherapy } \\
36 \mathrm{~Gy} \text { in } 6 \text { fractions }\end{array}$ & $\begin{array}{l}8.5 \text { months } \\
7.4 \text { months }\end{array}$ \\
\hline Martinez-Carrillo et al. 2014 (50) & $\begin{array}{l}46 \text { GBM } \\
41 \text { WHO III }\end{array}$ & $\begin{array}{l}\text { Stereotactic radiosurgery } \\
\text { Median } 18 \text { Gy }(14-20 \text { Gy })\end{array}$ & $\begin{array}{l}7.5 \text { months } \\
17.0 \text { months }\end{array}$ \\
\hline Bir et al. $2015(51)$ & $29 \mathrm{GBM}$ & Stereotactic radiosurgery $10-20 \mathrm{~Gy}$ & 7.9 months \\
\hline Pinzi et al. 2015 (52) & 128 High-grade & $\begin{array}{l}\text { Stereotactic radiosurgery or hypofractionated } \\
\text { Hypofractionated stereotactic radiotherapy }\end{array}$ & 11.5 months \\
\hline Shepherd et al. 1997 (53) & $33 \mathrm{GBM}$ & $\begin{array}{l}\text { Hypofractionated conformal radiotherapy } \\
\text { Escalation } 20-50 \mathrm{~Gy}\end{array}$ & 11.0 months \\
\hline Lederman et al. 2000 (54) & $88 \mathrm{GBM}$ & $\begin{array}{l}\text { Stereotactic hypofractionated radiotherapy } \\
\text { Median } 24 \text { Gy in } 4 \text { fractions }\end{array}$ & 7.0 months \\
\hline Grosu et al. 2005 (55) & 44 GBM & $\begin{array}{c}\text { Stereotactic hypofractionated radiotherapy } \\
36 \mathrm{PET} / \mathrm{SPECT} 30 \mathrm{~Gy} \\
8 \mathrm{CT} / \mathrm{MRI}(6 \times 5 \mathrm{~Gy})\end{array}$ & $\begin{array}{l}9.0 \text { months } \\
5.0 \text { months }\end{array}$ \\
\hline Fokas et al. 2009 (56) & $53 \mathrm{GBM}$ & $\begin{array}{l}\text { Stereotactic hypofractionated radiotherapy } \\
\qquad 30 \text { Gy in } 10 \text { fractions }\end{array}$ & 9.0 months \\
\hline Fogh et al. 2010 (57) & $\begin{array}{l}105 \text { GBM } \\
42 \text { WHO III }\end{array}$ & $\begin{array}{l}\text { Stereotactic hypofractionated radiotherapy } \\
\text { Median } 35 \text { Gy in } 10 \text { fractions }\end{array}$ & $\begin{array}{l}11.0 \text { months } \\
10.0 \text { months }\end{array}$ \\
\hline Dincoglan et al. 2015 (58) & $28 \mathrm{GBM}$ & $\begin{array}{l}\text { Stereotactic hypofractionated radiotherapy } \\
\qquad 25 \text { Gy in } 5 \text { fractions }\end{array}$ & 10.3 months \\
\hline \multicolumn{4}{|l|}{$\begin{array}{l}\text { Conventionally fractionated } \\
\text { (stereotactic) radiotherapy }\end{array}$} \\
\hline Arcicasa et al. 1999 (59) & $31 \mathrm{GBM}$ & $\begin{array}{l}\text { Fractionated conventional 2D-radiotherapy } \\
34.5 \mathrm{~Gy} \text { in } 23 \text { fractions }(1.5 \mathrm{~Gy} / \mathrm{F})\end{array}$ & 13.7 months \\
\hline Cho et al. 1999 (45) & $25 \mathrm{GBM}$ & $\begin{array}{l}\text { Conventional fractionated radiotherapy } \\
37.5 \text { Gy in } 15 \text { fractions }\end{array}$ & 12.0 months \\
\hline Koshi et al. 2007 (60) & $\begin{array}{l}11 \text { GBM } \\
14 \text { WHO III }\end{array}$ & $\begin{array}{c}\text { Stereotactic radiotherapy } \\
22 \mathrm{~Gy} \text { in } 8 \text { fractions/8F (+ hyperbaric oxygen) }\end{array}$ & $\begin{array}{l}11.0 \text { months } \\
19.0 \text { months }\end{array}$ \\
\hline Combs et al. 2008 (61) & $\begin{array}{c}8 \text { GBM } \\
10 \text { WHO III } \\
7 \text { low-grade }\end{array}$ & $\begin{array}{c}\text { Stereotactic radiotherapy } \\
36 \text { Gy in } 2 \text { Gy per fraction } \\
\left(+ \text { Temozolomide } 50 \mathrm{mg} / \mathrm{m}^{2}\right)\end{array}$ & 9.0 months \\
\hline Lee et al. 2016 (62) & $\begin{array}{l}21 \mathrm{GBM} \\
8 \text { WHO III } \\
7 \text { low-grade }\end{array}$ & $\begin{array}{l}\text { Conventional fractionated radiotherapy } \\
\text { (median dose } 45 \text { Gy) }\end{array}$ & $\begin{array}{l}10.0 \text { months } \\
\text { Not reported } \\
\text { Not reported }\end{array}$ \\
\hline
\end{tabular}

GBM, Glioblastoma; WHO, World Health Organization. 
GBM treated with high-precision radiation therapy (39 Gy, 3 Gy per fraction).

\section{Stereotactic Radiosurgery/Fractionated Stereotactic Radiotherapy}

In brain radiotherapy, stereotactic methods offer optimal precision of target definition whilst sparing dose to the surrounding tissues. Shepherd et al. reported on 29 recurrent high-grade glioma patients treated with a variety of doses of stereotactic hypofractionated re-irradiation who had a median survival of 11 months (53). This compared favorably to a matched cohort of patients treated with nitrosourea chemotherapy with a median survival of 7 months. In this study, a stereotactic radiotherapy dose of $>40$ Gy was found to be a significant predictor of radiation damage. There was also a trend towards higher risk of complications for larger volumes $\left(>35 \mathrm{~cm}^{3}\right)$ irradiated.

\section{Brachytherapy}

A review by Combs et al. reported on the available but limited data on brachytherapy for recurrent gliomas (72) (Table I). It should be noted that patients that are selected for brachytherapy are normally those with resectable tumors, good performance status and small volume of disease. High re-operation rates and radionecrosis incidence have repeatedly been reported using these techniques, but not in all studies.

\section{Combination Treatment}

Few studies have addressed the combination of chemotherapy with re-irradiation. Temozolomide and reirradiation has been found to be safe and effective. In a study combining fractionated stereotactic radiotherapy and concomitant temozolomide in 25 patients with recurrent gliomas, median survival from re-irradiation was 8 months. Treatment was completed in all patients without interruptions of more than 3 days and without severe sideeffects (55). Minniti et al. reported a median survival of 12.4 months in a cohort of 54 patients (73). Greenspoon et al. published a prospective cohort study that included 31 patients who survived for a median of 9 months (25-35 Gy in 5 fractions) (74).

Darakchiev et al. reported on 34 patients with recurrent GBM treated with re-resection and implantation with I-125 seeds and Gliadel wafers to the resection bed (75). They documented, in line with many other studies, that patients with a Karnofsky performance status less than 70 were more likely to have a worse outcome. One-year survival was $66 \%$ in this small, non randomiszed study and brain necrosis was observed in $24 \%$ of cases.
An international randomized phase II GBM study demonstrated that the experimental agent APG-101 (a CD95 ligand-binding fusion protein) given weekly until progression in addition to re-irradiation (36 Gy in 2-Gy fractions) significantly improved the primary end point, progression-free survival (76). According to the manufacturer's website, future development is ongoing (www.apogenix.com).

Gutin et al. combined hypofractionated stereotactic radiotherapy (30 Gy in 5 fractions) with bevacizumab (77). They documented a $50 \%$ response rate in the GBM population and a median overall survival of 12.5 months. Minniti et al. used a lower dose (25 Gy in 5 fractions) with bevacizumab or fotemustine (78). Overall and progressionfree survival were significantly better in the bevacizumab cohort. Combined with conventionally fractionated reirradiation (median dose $36 \mathrm{~Gy}$ ), median survival was 8.6 months (79). Compared with patients who did not receive bevacizumab $(n=44)$, the patients who received bevacizumab after radiosurgery $(n=11)$ in a case-control study had significantly prolonged progression-free survival (15 months vs. 7 months, $p=0.035$ ) and overall survival (18 months $v s$. 12 months, $p=0.005$ ) and were less likely to develop an adverse radiation effect ( $9 v s .46 \%, p=0.037$ ). Nine patients received irinotecan and one temozolomide with bevacizumab (80). A small randomized double-blind placebo-controlled trial with 14 patients suggested that bevacizumab might be a treatment option for patients with radiation necrosis (81). It is, therefore, difficult to assess radiological adverse effects and time to progression in patients who receive this or comparable, experimental anti-angiogenetic drugs.

Magnuson et al. performed a retrospective analysis of 23 patients with recurrent GBM (after standard radiotherapy/ temozolomide) treated with bevacizumab every 2 weeks until progression (82). Within 7-14 days of progression on bevacizumab, patients initiated re-irradiation to a dose of 54 Gy in 27 fractions using pulsed-reduced dose rate (PRDR) radiotherapy. The median planning target volume was large $\left(424 \mathrm{~cm}^{3}\right)$. At the start of re-irradiation, bevacizumab was given every 4 weeks for two additional cycles. The median survival after bevacizumab failure was 6.9 months. Re-irradiation was well-tolerated with no symptomatic grade 3-4 toxicities.

Data such as these may broaden the applicability of reirradiation further since co-treatment with new agents may improve response rates and/or improve the therapeutic ratio by reducing the risk of major side-effects.

\section{Relapsed Ependymoma and Medulloblastoma}

The same limitations discussed above also apply to the literature on relapsed ependymoma and medulloblastoma. One example is a recent study of 108 children with relapsed 
ependymoma where $66 \%$ received radiotherapy at relapse and $50 \%$ of older children were re-irradiated and where reirradiation was associated with better outcome (83). In a Canadian study of 47 patients who relapsed, 3-year overall survival was $7 \% \pm 6 \%$ and $81 \% \pm 12 \%$ for non-re-irradiated and re-irradiated patients, respectively $(p<0.0001)(84)$. However, a decline in intellectual function from pre- to post re-irradiation assessment was observed. Merchant et al. reported on a smaller series of 38 patients (85). Reirradiation included radiosurgery $(n=6)$, focal fractionated reirradiation $(n=13)$ or craniospinal irradiation ((CSI); $n=19)$. Their experience also suggests that re-irradiation might be a component of salvage therapy, even if it is not always without serious toxicity. Based on 18 lesions, Murai et al. reported that lesions receiving $>25$ Gy in 5 fractions or 21 Gy in 3 fractions did not recur within 1 year (86). Toxicity was limited to grade 2 or less. In a different study, 3 -year local control was 89\% (12 patients, fractionated stereotactic re-irradiation) and median event-free survival 3.4 years (87). In 6 patients, radionecrosis was diagnosed and three of these were symptomatic. Lobon et al. reported that 15 of 32 patients achieved greater progression-free survival after second radiotherapy than after initial irradiation (88). Five patients developed radionecrosis. For re-irradiated metastatic relapses $(n=17)$, median progressionfree survival was 6.8 years if CSI was administered, as compared to only 0.7 years in non-CSI cases, $p=0.07$.

In a small study, which included 25 patients with previously irradiated recurrent medulloblastoma, a trend towards better event-free survival was seen in patients who received additional radiotherapy as part of their retrieval therapy (89). Patients without gross disease at re-irradiation had favorable disease-free survival (90). High local control rates but significant rates of out-of-field metastases after reirradiation for medulloblastoma were also reported by Milker-Zabel et al. (91). According to Wetmore et al., the use of radiotherapy as a component of salvage treatment may prolong survival (92). The benefit was greatest for relapsed standard risk patients. However, imaging-detected necrosis was also more frequent after re-irradiation.

\section{Relapsed Meningioma}

Wojcieszynski et al. (93) reviewed an institutional database of patients with meningioma treated with stereotactic radiosurgery or fractionated stereotactic radiotherapy who underwent a second course for recurrent disease (median dose at relapse $15 \mathrm{~Gy}$ and $50.4 \mathrm{~Gy}$, respectively). Three percent of their patients were re-irradiated. The median time interval was 40 months. After a median follow-up of 32 months, 11 of 19 patients (58\%) experienced disease progression. Median time to second progression was 10 months. Freedom from progression at one year was lower in patients with grade II or III tumors compared to those with grade I or unknown histology (17\% compared to $92 \%$, $p=0.005)$. Cox regression showed that a grade II-III tumor affects progression-free survival, with a hazard ratio of 5.37 $(p=0.011)$. Median time to progression for patients with grade II-III tumors was eight months. This end point was not reached for patients with grade I/unknown tumors. The Kaplan-Meier estimate for median survival time was 90 months. There were no reported serious (grade $\geq 3$ ) toxic events attributed to re-irradiation.

\section{Conclusion}

There is a patient group with recurrent gliomas and other cranial tumors for whom re-irradiation may be appropriate. This recommendation is also reflected in two recent clinical practice guidelines $(94,95)$. The available literature suggests that re-irradiation is safe in well selected patients; however, more prospective data are needed to support this conclusion. With advances in functional imaging technology, new approaches to target definition are under investigation. Due to a lack of randomized studies, the additional benefit of chemotherapy is unknown, but several combinations seem promising for further studies.

Prospective trials are needed comparing re-irradiation to newer systemic agents or re-irradiation in combination with newer agents. These include different strategies of immunotherapy and vaccination. Despite a large body of clinical work, no standard protocol for re-irradiation of brain tumors has been defined yet. The heterogeneous dose definitions (prescription to different surrounding isodoses or the ICRU reference point) and individualized sequence of second- and third-line therapies also make comparisons between studies difficult. Some studies have used concomitant chemotherapy or bevacizumab, which may have been a confounding factor. The generally small study size is dangerous as inclusion of patients with a more favorable tumor biology in some studies could result in better survival and erroneous conclusions about treatment efficacy when comparing different subgroups. The impact of certain biological features has only been realized in recent years (9698). In addition, some studies included patients with histological grade change, e.g. initial radiotherapy for grade II or III tumor and re-irradiation for GBM. The latter group is now regarded a biologically heterogeneous disease (96).

Ideally, radiotherapy should be highly conformal to keep the treated volume as small as possible and reduce late sideeffects to organs at risk and other brain tissue. Many series suggest that limiting the target volume to approximately 4-5 $\mathrm{cm}$ minimizes the risk of toxicity and recommend that if larger volumes are being targeted, then, consideration should be made to reducing the dose. As evident from the review of treated volumes with different modalities, such as single- 
Table II. Examples of re-irradiation techniques and regimens for patients with recurrent supratentorial gliomas.

\begin{tabular}{|c|c|c|}
\hline Low-volume recurrence* & $\begin{array}{l}\text { Consider SRS, brachytherapy or FSRT, } \\
\text { e.g. } 35 \text { Gy in } 5 \text { fractions }\end{array}$ & $\begin{array}{c}\text { Proximity to critical structures might require reduced EQD2, } \\
e . g \text {. by reducing fraction size ( } 35 \mathrm{~Gy} \text { in } 10 \text { fractions) }\end{array}$ \\
\hline Intermediate volume recurrence ${ }^{* *}$ & Consider FSRT, e.g. $30 \mathrm{~Gy}$ in 5 fractions & $\begin{array}{l}\text { Proximity to critical structures might require reduced EQD2, } \\
\text { e.g. by reducing fraction size ( } 30 \mathrm{~Gy} \text { in } 10 \text { fractions) }\end{array}$ \\
\hline Large-volume recurrence & Consider FSRT, e.g. $25 \mathrm{~Gy}$ in 5 fractions & $\begin{array}{l}\text { Proximity to critical structures might require reduced EQD2, } \\
\text { e.g. by reducing fraction size ( } 36 \text { Gy in } 18 \text { fractions) }\end{array}$ \\
\hline
\end{tabular}

SRS, Stereotactic radiosurgery; FSRT, fractionated stereotactic radiotherapy; EQD2, biologically equivalent dose in 2-Gy fractions. *MartinezCarrillo et al. (50) have summarized volume data from 20 radiosurgery studies. The median volume in these studies ranged from 4.7 to $28 \mathrm{~cm}^{3}$, for a median of $10 \mathrm{~cm}^{3}$. **In stereotactic hypofractionated radiotherapy studies (Table I), the median volume ranged from 18 to $35 \mathrm{~cm}^{3}$ (median=27.5). Ongoing clinical trials: NCT02709226 (FSRT dose escalation from 10 fractions of 3.5 Gy to 12 and 14 fractions), NCT01925573 (FSRT 10 fractions of 3.5Gy or 5 fractions of 6Gy (physicians choice) with tumor-treating fields and bevacizumab), NCT01252459 (FSRT 13 fractions of 3 Gy, different imaging protocols ( \pm PET) for target volume delineation), NCT01464177 (FSRT 5 fractions of 5 Gy or 7 Gy), NCT01666600 (18 fractions of 2 Gy), NCT02149459 (10 fractions of 3-3.5 Gy).

dose and fractionated stereotactic irradiation (Table II), some institutions preferred hypofractionation for recurrences that others treated with single doses. This finding reflects the lack of universally agreed dose-constraints for re-irradiation. Pooled analyses from several institutions are necessary to develop a more homogeneous clinical practice.

Most recurrent glioma patients will have received the equivalent of 54-60 Gy in 1.8-2 Gy per fraction when they were initially treated and, therefore, no more than $40 \mathrm{~Gy}$ equivalent in a hypofractionated regime should be delivered when re-irradiating aiming to keep the total dose less than 100 Gy (64). Fraction sizes of 3-5 Gy appear to be welltolerated in limited-volume recurrences $(<75 \mathrm{ml})$ as long as the total dose is limited to 30-35 Gy. Table II shows examples of possible fractionation regimens. A maximum dose of 20 Gy with concurrent chemotherapy has been prescribed in patients with diffuse intrinsic pontine glioma (99). This modest dose improved symptoms and delayed progression with minimal side-effects. Available data do not suggest that there is an obvious limitation on the time between treatment courses, although many clinicians would not treat within a year as these patients are likely to have primary treatment resistance.

Performance status of the patient and the potential impact on their quality of life should be taken into account. Consideration should be given to the impact of prolonged treatment courses in the context of poor prognosis disease. There are very few data on the quality of life following re-irradiation, which is an important consideration in a poor prognostic group.

\section{References}

1 Stupp R, Hegi ME, Mason WP van den Bent MJ, Taphoorn MJ, Janzer RC, Ludwin SK, Allgeier A, Fisher B, Belanger K, Hau P, Brandes AA, Gijtenbeek J, Marosi C, Vecht CJ, Mokhtari K, Wesseling P, Villa S, Eisenhauer E, Gorlia T, Weller M, Lacombe
D, Cairncross JG and Mirimanoff RO; European Organisation for Research and Treatment of Cancer Brain Tumour and Radiation Oncology Groups; National Cancer Institute of Canada Clinical Trials Group: Effects of radiotherapy with concomitant and adjuvant temozolomide versus radiotherapy alone on survival in glioblastoma in a randomised phase II study: 5-year analysis of the EORTC-NCIC trial. Lancet Oncol 10: 459-466, 2009.

2 Stupp R, Taillibert S, Kanner AA, Kesari S, Steinberg DM, Toms SA, Taylor LP, Lieberman F, Silvani A, Fink KL, Barnett GH, Zhu JJ, Henson JW, Engelhard HH, Chen TC, Tran DD, Sroubek J, Tran ND, Hottinger AF, Landolfi J, Desai R, Caroli M, Kew Y, Honnorat J, Idbaih A, Kirson ED, Weinberg U, Palti Y, Hegi ME and Ram Z: Maintenance therapy with tumor-treating fields plus temozolomide vs temozolomide alone for glioblastoma: A randomized clinical trial. JAMA 314: 2535-2543, 2015.

3 Niyazi M, Brada M, Chalmers AJ, Combs SE, Erridge SC, Fiorentino A, Grosu AL, Lagerwaard FJ, Minniti G, Mirimanoff RO, Ricardi U, Short SC, Weber DC and Belka C: ESTROACROP guideline "target delineation of glioblastomas". Radiother Oncol 118: 35-42, 2016.

4 Brem H, Piantadosi S, Burger PC, Walker M, Selker R, Vick NA, Black K, Sisti M, Brem S and Mohr G: Placebo controlled trial of safety and efficacy of intraoperative controlled delivery by biodegradable polymers of chemotherapy for recurrent gliomas. Lancet 345: 1008-1012, 1995.

5 Bloch O, Han SJ, Cha S, Sun MZ, Aghi MK, McDermott MW, Berger MS and Parsa AT: Impact of extent of resection for recurrent glioblastoma on overall survival: clinical article. J Neurosurg 117: 1032-1038, 2012.

6 Oppenlander ME, Wolf AB, Snyder LA, Bina R, Wilson JR, Coons SW, Ashby LS, Brachman D, Nakaji P, Porter RW, Smith KA, Spetzler RF and Sanai N: An extent of resection threshold for recurrent glioblastoma and its risk for neurological morbidity. J Neurosurg 120: 846-853, 2014.

7 Suchorska B, Weller M, Tabatabai G, Senft C, Hau P, Sabel MC, Herrlinger U, Ketter R, Schlegel U, Marosi C, Reifenberger G, Wick W, Tonn JC and Wirsching HG: Complete resection of contrast-enhancing tumor volume is associated with improved survival in recurrent glioblastoma-results from the DIRECTOR trial. Neuro Oncol 18: 549-556, 2016. 
8 Wong ET, Hess KR, Gleason MJ, Jaeckle KA, Kyritsis AP, Prados MD, Levin VA and Yung WK: Outcomes and prognostic factors in recurrent glioma patients enrolled into phase II clinical trials. J Clin Oncol 17: 2572-2579, 1999.

9 Ballman KV, Buckner JC, Brown PD, Giannini C, Flynn PJ, LaPlant BR and Jaeckle KA: The relationship between sixmonth progression-free survival and 12-month overall survival end points for phase II trials in patients with glioblastoma multiforme. Neurooncol 9: 29-38, 2007.

10 Huncharek $\mathrm{M}$ and Muscat $\mathrm{J}$ : Treatment of recurrent high grade astrocytoma; results of a systematic review of 1,415 patients. Anticancer Res 18: 1303-1311, 1998.

11 Yung WK, Prados MD, Yaya-Tur R, Rosenfeld SS, Brada M, Friedman HS, Albright R, Olson J, Chang SM, O'Neill AM, Friedman AH, Bruner J, Yue N, Dugan M, Zaknoen S and Levin VA: Multicentre phase II trial of temozolomide in patients with anaplastic astrocytoma or anaplastic oligoastrocytoma at first relapse. Temodal Brain Tumor Group. J Clin Oncol 17: 27622771, 1999.

12 Wick W, Steinbach JP, Küker WM, Dichgans J, Bamberg M and Weller M: One week on/one week off: a novel active regime of temozolomide for recurrent glioblastoma. Neurology 62: 21132115, 2004.

13 Norden AD, Lesser GJ, Drappatz J, Ligon KL, Hammond SN, Lee EQ, Reardon DR, Fadul CE, Plotkin SR, Batchelor TT, Zhu JJ, Beroukhim R, Muzikansky A, Doherty L, Lafrankie D, Smith K, Tafoya V, Lis R, Stack EC, Rosenfeld MR and Wen PY: Phase 2 study of dose-intense temozolomide in recurrent glioblastoma. Neuro Oncol 15: 930-935, 2013.

14 Weller M, Tabatabai G, Kästner B, Felsberg J, Steinbach JP, Wick A, Schnell O, Hau P, Herrlinger U, Sabel MC, Wirsching HG, Ketter R, Bähr O, Platten M, Tonn JC, Schlegel U, Marosi C, Goldbrunner R, Stupp R, Homicsko K, Pichler J, Nikkhah G, Meixensberger J, Vajkoczy P, Kollias S, Hüsing J, Reifenberger G and Wick W; DIRECTOR Study Group: MGMT promoter methylation is a strong prognostic biomarker for benefit from doseintensified temozolomide rechallenge in progressive glioblastoma: the DIRECTOR trial. Clin Cancer Res 21: 2057-2064, 2015.

15 Soffietti R, Trevisan E, Bertero L, Cassoni P, Morra I, Fabrini MG, Pasqualetti F, Lolli I, Castiglione A, Ciccone $\mathrm{G}$ and Rudà $\mathrm{R}$ : Bevacizumab and fotemustine for recurrent glioblastoma: a phase II study of AINO (Italian Association of NeuroOncology). J Neurooncol 116: 533-541, 2014

16 Taal W, Oosterkamp HM, Walenkamp AM, Dubbink HJ, Beerepoot LV, Hanse MC, Buter J, Honkoop AH, Boerman D, de Vos FY, Dinjens WN, Enting RH, Taphoorn MJ, van den Berkmortel FW, Jansen RL, Brandsma D, Bromberg JE, van Heuvel I, Vernhout RM, van der Holt B and van den Bent MJ: Single-agent bevacizumab or lomustine versus a combination of bevacizumab plus lomustine in patients with recurrent glioblastoma (BELOB trial): A randomised controlled phase 2 trial. Lancet Oncol 15: 943-953, 2014.

17 Wick W, Brandes AA, Gorlia T, Bendszus M, Sahm F, Taal W, Taphoorn M, Domont J, Idbaih A, Campone M, Clement PM, Stupp R, Fabbro M, Le Rhun E, Dubois F, Klein M, Platten M, Weller M, Golfinopoulos V and van den Bent MJ: EORTC 26101 phase III trial exploring the combination of bevacizumab and lomustine in patients with first progression of a glioblastoma. Accessed online at http://meetinglibrary.asco.org/ content/169696-176, 2016.
18 Scorsetti M, Navarria P, Pessina F, Ascolese AM, D'Agostino G, Tomatis S, De Rose F, Villa E, Maggi G, Simonelli M, Clerici E, Soffietti R, Santoro A, Cozzi L and Bello L: Multimodality therapy approaches, local and systemic treatment, compared with chemotherapy alone in recurrent glioblastoma. BMC Cancer 15: 486, 2015.

19 Müller K, Henke G, Pietschmann S, van Gool S, De Vleeschouwer S, von Bueren AO, Compter I, Friedrich C, Matuschek C, Klautke G, Kortmann RD, Hundsberger T and Baumert BG: Re-irradiation or re-operation followed by dendritic cell vaccination? Comparison of two different salvage strategies for relapsed high-grade gliomas by means of a new prognostic model. J Neurooncol 124: 325-332, 2015.

20 Tofilon $\mathrm{P}$ and Fike J: The radioresponse of the central nervous system: a dynamic process. Radiat Res 153: 357-370, 2000.

21 Wong CS and van der Kogel AJ: Mechanisms of radiation injury to the central nervous system: implications for neuroprotection. Mol Interv 4: 273-284, 2004.

22 Wong CS, Fehlings MG and Sahgal A: Pathobiology of radiation myelopathy and strategies to mitigate injury. Spinal Cord 53: 574-580, 2015.

23 Nieder C, Milas L and Ang KK: Tissue tolerance to reirradiation. Semin Radiat Oncol 10: 200-209, 2000.

24 Sminia P and Mayer R: External beam radiotherapy of recurrent glioma: radiation tolerance of the human brain. Cancers (Basel) 4: 379-399, 2012.

25 Withers HR: Biological basis for altered fractionation schemes. Cancer 55: 2086-2095, 1985

26 Medin PM, Foster RD, van der Kogel AJ, Sayre JW, McBride WH and Solberg TD: Spinal cord tolerance to reirradiation with single-fraction radiosurgery: a swine model. Int J Radiat Oncol Biol Phys 83: 1031-1037, 2012.

27 Ang K, Jiang GL and Feng Y: Extent and kinetics of recovery of occult spinal cord injury. Int J Radiat Oncol Biol Phys 50: 1013-1020, 2001.

28 Elias WJ, Khaled M, Hilliard JD, Aubry JF, Frysinger RC, Sheehan JP, Wintermark M and Lopes MB: A magnetic resonance imaging, histological, and dose modelling comparison of focused ultrasound, radiofrequency, and Gamma Knife radiosurgery lesions in swine thalamus. J Neurosurg 119: 307-317, 2013.

29 Acharya MM, Patel NH, Craver BM, Tran KK, Giedzinski E, Tseng BP, Parihar VK and Limoli CL: Consequences of low dose ionizing radiation exposure on the hippocampal microenvironment. PLoS One 10: e0128316, 2015.

30 Morganti JM, Jopson TD, Liu S, Gupta N and Rosi S: Cranial irradiation alters the brain's microenvironment and permits CCR2+ macrophage infiltration. PLoS One 9: e93650, 2014.

31 Carson K, Grossman S and Fisher J: Prognostic factors for survival in adult patients with recurrent glioma enrolled onto the new approaches to brain tumor therapy CNS consortium Phase I and Phase II clinical trials. J Clin Oncol 25: 2601-2606, 2007.

32 Combs SE, Edler L, Rausch R, Welzel T, Wick W and Debus J: Generation and validation of a prognostic score to predict outcome after re-irradiation of recurrent glioma. Acta Oncol 52: 147-152, 2013.

33 Scholtyssek F, Zwiener I, Schlamann A, Seidel C, Meixensberger J, Bauer M, Hoffmann KT, Combs SE, von Bueren AO, Kortmann $\mathrm{RD}$ and Müller K: Reirradiation in progressive high-grade gliomas: outcome, role of concurrent chemotherapy, prognostic factors and validation of a new prognostic score with an independent patient cohort. Radiat Oncol 8: 161, 2013. 
34 Niyazi M, Flieger M, Ganswindt U, Combs SE and Belka C: Validation of the prognostic Heidelberg re-irradiation score in an independent mono-institutional patient cohort. Radiat Oncol 9: 128,2014

35 Müller K, Henke G, Compter I, von Bueren AO, Friedrich C, Janssens G, Kramm CM, Hundsberger T, Paulsen F, Kortmann RD, Zwiener I and Baumert BG: External validation of a prognostic model estimating the survival of patients with recurrent high-grade gliomas after reirradiation. Pract Radiat Oncol 5: e143-150, 2015.

36 Scharfen CO, Sneed PK, Wara WM, Larson DA, Phillips TL, Prados MD, Weaver KA, Malec M, Acord P and Lamborn KR: High activity iodine-125 interstitial implant for gliomas. Int J Radiat Oncol Biol Phys 24: 583-591, 1992.

37 Sneed PK, McDermott MW and Gutin PH: Interstitial brachytherapy procedures for brain tumors. Semin Surg Oncol 13: 157-166, 1997.

38 Simon JM, Cornu P, Boisserie G, Hasboun D, Tep B, Hardiman C, Valery CA, Delattre JY, Dormont D, Baillet F and Mazeron $\mathrm{JJ}$ : Brachytherapy of glioblastoma recurring in previously irradiated territory: predictive value of tumor volume. Int $\mathbf{J}$ Radiat Oncol Biol Phys 53: 67-74, 2002.

39 Gabayan AJ, Green SB, Sanan A, Jenrette J, Schultz C, Papagikos M, Tatter SP, Patel A, Amin P, Lustig R, Bastin KT, Watson G, Burri S and Stea B: Gliasite brachytherapy for treatment of recurrent malignant gliomas: a retrospective multiinstitutional analysis. Neurosurgery 58: 701-709, 2006.

40 Tselis N, Kolotas C, Birn G, Röddiger S, Filipowicz I, Kontova M, Fountzilas G, Selviaridis P, Baltas D, Heyd R, Anagnostopoulos $\mathrm{G}$ and Zamboglou N: CT guided interstitial HDR brachytherapy for recurrent glioblastoma multiforme. Long term results. Strahlenther Onkol 183: 563-570, 2007.

41 Fabrini MG, Perrone F, De Franco L, Pasqualetti F, Grespi S, Vannozzi $\mathrm{R}$ and Cionini L: Perioperative high-dose-rate brachytherapy in the treatment of recurrent malignant gliomas. Strahlenther Onkol 185: 524-529 (Erratum:703), 2009.

42 Kickingereder P, Hamisch C, Suchorska B, Galldiks N, VisserVandewalle V, Goldbrunner R, Kocher M, Treuer H, Voges J and Ruge MI: Low-dose rate stereotactic iodine-125 brachytherapy for the treatment of inoperable primary and recurrent glioblastoma: single-center experience with 201 cases. J Neurooncol 120: 615-623, 2014.

43 Schwartz C, Romagna A, Thon N, Niyazi M, Watson J, Belka C, Tonn JC, Kreth FW and Nachbichler SB: Outcome and toxicity profile of salvage low-dose-rate iodine- 125 stereotactic brachytherapy in recurrent high-grade gliomas. Acta Neurochir (Wien) 157: 1757-1764, 2015

44 Shrieve DC, Alexander E 3rd, Wen PY, Fine HA, Kooy HM, Black PM and Loeffler JS: Comparison of stereotactic radiosurgery and brachytherapy in the treatment of recurrent glioblastoma multiforme. Neurosurgery 36: 275-282, 1995.

45 Cho KH, Hall WA, Gerbi BJ, Higgins PD, McGuire WA and Clark HB: Single dose versus fractionated stereotactic radiotherapy for recurrent gliomas. Int J Radiat Oncol Biol Phys 45: 1133-1141, 1999.

46 Combs SE, Widmer V, Thilman C, Hof H, Debus J and SchulzErtner D: Stereotactic radiosurgery (SRS): treatment option for recurrent glioblastoma multiforme. Cancer 104: 2168-2173, 2005.

47 Combs SE, Thilmann C, Edler L, Debus J and Schulz-Ertner D: Efficacy of fractionated stereotactic re-irradiation in recurrent gliomas: long term results in 172 patients treated in a single institution. J Clin Oncol 23: 8863-8869, 2005.

48 Kong DS, Lee JI, Park K, Kim JH, Lim DH and Nam DH: Efficacy of stereotactic radiosurgery as a salvage treatment for recurrent malignant gliomas. Cancer 112: 2046-2051, 2008.

49 Patel M, Siddiqui F, Jin JY, Mikkelsen T, Rosenblum M, Movsas B and Ryu S: Salvage re-irradiation for recurrent glioblastoma with radiosurgery: radiographic response and improved survival J Neurooncol 92: 185-191, 2009.

50 Martínez-Carrillo M, Tovar-Martín I, Zurita-Herrera M, Del Moral-Ávila R, Guerrero-Tejada R, Saura-Rojas E, OsorioCeballos JL, Arrebola-Moreno JP and Expósito-Hernández J: Salvage radiosurgery for selected patients with recurrent malignant gliomas. Biomed Res Int 2014: 657953, 2014.

51 Bir SC, Connor DE Jr, Ambekar S, Wilden JA and Nanda A: Factors predictive of improved overall survival following stereotactic radiosurgery for recurrent glioblastoma. Neurosurg Rev 38: 705-713, 2015.

52 Pinzi V, Orsi C, Marchetti M, Milanesi IM, Bianchi LC, DiMeco F, Cuccarini V, Farinotti M, Ferroli P, Finocchiaro G, Franzini A, Fumagalli M, Silvani A and Fariselli L: Radiosurgery reirradiation for high-grade glioma recurrence: a retrospective analysis. Neurol Sci 36: 1431-1440, 2015.

53 Shepherd SF, Laing RW, Cosgrove VP, Warrington AP, Hines F, Ashley SE and Brada M: Hypofractionated stereotactic radiotherapy in the management of recurrent glioma. Int J Radiat Oncol Biol Phys 37: 393-398, 1997.

54 Lederman G, Wronski M and Arbit E: Treatment of recurrent glioblastoma multiforme using fractionated stereotactic radiosurgery and concurrent paclitaxel. Am J Clin Oncol 23: $155-159,2000$

55 Grosu AL, Weber WA, Franz M, Stärk S, Piert M, Thamm R, Gumprecht H, Schwaiger M, Molls $M$ and Nieder C: Reirradiation of recurrent high grade gliomas using Amino Acid PET (SPECT)/CT/MRI fusion to determine gross tumor volume for stereotactic fractionated radiotherapy. Int J Radiat Oncol Biol Phys 63: 511-519, 2005.

56 Fokas E, Wacker U, Gross MW, Henzel M, Encheva E and Engenhart-Cabillic R: Hypofractionated stereotactic reirradiation of recurrent glioblastomas: a beneficial treatment option after high dose radiotherapy. Strahlenther Onkol 185: 235-240, 2009.

57 Fogh SE, Andrews DW, Glass J, Curran W, Glass C, Champ C, Evans JJ, Hyslop T, Pequignot E, Downes B, Comber E, Maltenfort M, Dicker AP and Werner-Wasik M: Hypofractionated stereotactic radiation therapy: an effective therapy for recurrent high-grade gliomas. J Clin Oncol 28: 3048-3053, 2010.

58 Dincoglan F, Beyzadeoglu M, Sager O, Demiral S, Gamsiz H, Uysal B, Ebruli C, Akin M, Oysul K, Sirin S and Dirican B: Management of patients with recurrent glioblastoma using hypofractionated stereotactic radiotherapy. Tumori 101: 179-184, 2015.

59 Arcicasa M, Roncadin M, Bidoli E, Dedkov A, Gigante M and Trovò MG: Re-irradiation and lomustine in patients with relapsed high grade gliomas. Int J Radiat Oncol Biol Phys 43: 789-793, 1999.

60 Kohshi K, Yamamoto H, Nakahara A, Katoh T and Takagi M: Fractionated stereotactic radiotherapy using gamma unit after hyperbaric oxygenation on recurrent high-grade gliomas. J Neurooncol 82: 297-303, 2007. 
61 Combs S, Bischof M and Welzel T: Radiochemotherapy with temozolomide as re-irradiation using high precision fractionated stereotactic radiotherapy (FSRT) in patients with recurrent gliomas. J Neurooncol 89: 205-210, 2008.

62 Lee J, Cho J, Chang JH and Suh CO: Re-irradiation for recurrent gliomas: treatment outcomes and prognostic factors. Yonsei Med J 57: 824-830, 2016.

63 Nieder C, Adam M, Molls M and Grosu AL: Therapeutic options for recurrent high-grade glioma in adult patients: recent advances. Crit Rev Oncol Hematol 60: 181-193, 2006.

64 Mayer R and Sminia P: Reirradiation tolerance of the human brain. Int J Radiat Oncol Biol Phys 70: 1350-1360, 2008.

65 Chan JL, Lee SW and Fraass BA: Survival and failure patterns of high grade gliomas after three-dimensional conformal radiotherapy. J Clin Oncol 20: 1635-1642, 2002.

66 Chen W: Clinical applications of PET in brain tumors. J Nucl Med 48: 1468-1481, 2007.

67 Bobek-Billewicz B, Stasik-Pres $G$ and Majchrzak $H$ : Differentiation between brain tumor recurrence and radiation injury using perfusion, diffusion-weighted imaging and MR spectroscopy. Folia Neuropathol 48: 81-92, 2010.

68 Grosu AL and Weber WA: PET for radiation treatment planning of brain tumors. Radiother Oncol 96: 325-327, 2010.

69 Ryken TC, Aygun N, Morris J, Schweizer M, Nair R, Spracklen C, Kalkanis SN and Olson JJ; AANS/CNS Joint Guidelines Committee: The role of imaging in the management of progressive glioblastoma: a systematic review and evidence-based clinical practice guideline. J Neurooncol 118: 435-460, 2014.

70 Miwa K, Matsuo M, Ogawa S, Shinoda J, Yokoyama K, Yamada $\mathrm{J}$, Yano $\mathrm{H}$ and Iwama T: Re-irradiation of recurrent glioblastoma multiforme using 11C-methionine PET/CT/MRI image fusion for hypofractionated stereotactic radiotherapy by intensity modulated radiation therapy. Radiat Oncol 9: 181, 2014.

71 Grosu AL, Astner ST, Riedel E, Nieder C, Wiedenmann N, Heinemann F, Schwaiger M, Molls M, Wester HJ and Weber WA: An interindividual comparison of O-(2-[18 F] fluoroethyl)L-tyrosine (FET)- and L-[methyl-11 C] methionine (MET)-PET in patients with brain gliomas and metastases. Int $\mathrm{J}$ Radiat Oncol Biol Phys 81: 1049-1058, 2011.

72 Combs S, Debus J and Schulz-Ertner D: Radiotherapeutic alternatives for previously irradiated recurrent gliomas. BMC Cancer 7: 167, 2007.

73 Minniti G, Scaringi C, De Sanctis V, Lanzetta G, Falco T, Di Stefano D, Esposito V and Enrici RM: Hypofractionated stereotactic radiotherapy and continuous low-dose temozolomide in patients with recurrent or progressive malignant gliomas. J Neurooncol 111: 187-194, 2013.

74 Greenspoon JN, Sharieff W, Hirte H, Overholt A, Devillers R, Gunnarsson $\mathrm{T}$ and Whitton A: Fractionated stereotactic radiosurgery with concurrent temozolomide chemotherapy for locally recurrent glioblastoma multiforme: a prospective cohort study. Onco Targets Ther 7: 485-490, 2014.

75 Darakchiev B, Albright R and Breneman J: Safety and efficacy of permanent iodine-125 seed implants and carmustine wafers in patients with recurrent glioblastoma multiforme. J Neurosurg 108: 236-242, 2008.

76 Wick W, Fricke H, Junge K, Kobyakov G, Martens T, Heese O, Wiestler B, Schliesser MG, von Deimling A, Pichler J, Vetlova E, Harting I, Debus J, Hartmann C, Kunz C, Platten M, Bendszus $\mathrm{M}$ and Combs SE: A phase II, randomized, study of weekly APG101+reirradiation versus reirradiation in progressive glioblastoma. Clin Cancer Res 20: 6304-6313, 2014.

77 Gutin P, Iwamoto F, Beal K, Mohile NA, Karimi S, Hou BL, Lymberis S, Yamada Y, Chang J and Abrey LE: Safety and efficacy of bevacizumab with hypofractionated stereotactic irradiation for recurrent malignant gliomas. Int J Radiat Oncol Biol Phys 75: 156-163, 2009.

78 Minniti G, Agolli L, Falco T, Scaringi C, Lanzetta G, Caporello P, Osti MF, Esposito V and Enrici RM: Hypofractionated stereotactic radiotherapy in combination with bevacizumab or fotemustine for patients with progressive malignant gliomas. J Neurooncol 122: 559-566, 2015.

79 Flieger M, Ganswindt U, Schwarz SB, Kreth FW, Tonn JC, la Fougère $\mathrm{C}$, Ertl L, Linn J, Herrlinger U, Belka C and Niyazi M: Re-irradiation and bevacizumab in recurrent high-grade glioma: an effective treatment option. J Neurooncol 117: 337-345, 2014.

80 Park KJ, Kano H, Iyer A, Liu X, Niranjan A, Flickinger JC, Lieberman FS, Lunsford LD and Kondziolka D: Salvage gamma knife stereotactic radiosurgery followed by bevacizumab for recurrent glioblastoma multiforme: a case-control study. J Neurooncol 107: 323-333, 2012.

81 Levin VA, Bidaut L, Hou P, Kumar AJ, Wefel JS, Bekele BN, Grewal J, Prabhu S, Loghin M, Gilbert MR and Jackson EF: Randomized double-blind placebo-controlled trial of bevacizumab therapy for radiation necrosis of the central nervous system. Int J Radiat Oncol Biol Phys 79: 1487-1495, 2011.

82 Magnuson W, Ian Robins H, Mohindra P and Howard S: Large volume reirradiation as salvage therapy for glioblastoma after progression on bevacizumab. J Neurooncol 117: 133-139, 2014.

83 Messahel B, Ashley S, Saran F, Ellison D, Ironside J, Phipps K, Cox T, Chong WK, Robinson K, Picton S, Pinkerton CR, Mallucci C, Macarthur D, Jaspan T, Michalski A and Grundy RG; Children's Cancer Leukaemia Group Brain Tumour Committee: Relapsed intracranial ependymoma in children in the UK: patterns of relapse, survival and therapeutic outcome. Eur J Cancer 45: 1815-1823, 2009.

84 Bouffet E, Hawkins CE, Ballourah W, Taylor MD, Bartels UK, Schoenhoff N, Tsangaris E, Huang A, Kulkarni A, Mabbot DJ, Laperriere $\mathrm{N}$ and Tabori $\mathrm{U}$ : Survival benefit for pediatric patients with recurrent ependymoma treated with reirradiation. Int $\mathbf{J}$ Radiat Oncol Biol Phys 83: 1541-1548, 2012.

85 Merchant TE, Boop FA, Kun LE and Sanford RA: A retrospective study of surgery and reirradiation for recurrent ependymoma. Int J Radiat Oncol Biol Phys 71: 87-97, 2008.

86 Murai T, Sato K, Iwabuchi M, Manabe Y, Ogino H, Iwata H, Tatewaki K, Yokota N, Ohta S and Shibamoto Y: Re-irradiation of recurrent anaplastic ependymoma using radiosurgery or fractionated stereotactic radiotherapy. Jpn J Radiol 34: 211-218 (Erratum: 219), 2016.

87 Hoffman LM, Plimpton SR, Foreman NK, Stence NV, Hankinson TC, Handler MH, Hemenway MS, Vibhakar R and Liu AK: Fractionated stereotactic radiosurgery for recurrent ependymoma in children. J Neurooncol 116: 107-111, 2014.

88 Lobon MJ, Bautista F, Riet F, Dhermain F, Canale S, Dufour C, Blauwblomme T, Zerah M, Beccaria K, Saint-Rose C, Puget S, Carrie C, Lartigau E, Bondiau PY, Valteau-Couanet D, Grill J and Bolle S: Re-irradiation of recurrent pediatric ependymoma: modalities and outcomes: a twenty-year survey. Springerplus 5: 879, 2016. 
89 Dunkel IJ, Gardner SL, Garvin JH Jr, Goldman S, Shi W and Finlay JL: High-dose carboplatin, thiotepa, and etoposide with autologous stem cell rescue for patients with previously irradiated recurrent medulloblastoma. Neuro Oncol 12: 297-303, 2010 .

90 Bakst RL, Dunkel IJ, Gilheeney S, Khakoo Y, Becher O, Souweidane MM and Wolden SL: Reirradiation for recurrent medulloblastoma. Cancer 117: 4977-4982, 2011.

91 Milker-Zabel S, Zabel A, Thilmann C, Zuna I, Hoess A, Wannenmacher $\mathrm{M}$ and Debus J: Results of three-dimensional stereotactically-guided radiotherapy in recurrent medulloblastoma. J Neurooncol 60: 227-233, 2002.

92 Wetmore C, Herington D, Lin T, Onar-Thomas A, Gajjar A and Merchant TE: Reirradiation of recurrent medulloblastoma: does clinical benefit outweigh risk for toxicity? Cancer 120: 37313737, 2014.

93 Wojcieszynski AP, Ohri N, Andrews DW, Evans JJ, Dicker AP and Werner-Wasik M: Reirradiation of recurrent meningioma. J Clin Neurosci 19: 1261-1264, 2012.

94 Ryu S, Buatti JM, Morris A, Kalkanis SN, Ryken TC and Olson JJ; AANS/CNS Joint Guidelines Committee: The role of radiotherapy in the management of progressive glioblastoma: a systematic review and evidence-based clinical practice guideline. J Neurooncol 118: 489-499, 2014.
95 Nahed BV, Redjal N, Brat DJ, Chi AS, Oh K, Batchelor TT, Ryken TC, Kalkanis SN and Olson JJ: Management of patients with recurrence of diffuse low grade glioma: A systematic review and evidence-based clinical practice guideline. J Neurooncol 125: 609-630, 2015.

96 Aldape K, Zadeh G, Mansouri S, Reifenberger G and von Deimling A: Glioblastoma: pathology, molecular mechanisms and markers. Acta Neuropathol 129: 829-848, 2015.

97 Chen R, Ravindra VM, Cohen AL, Jensen RL, Salzman KL, Prescot AP and Colman H: Molecular features assisting in diagnosis, surgery, and treatment decision making in low-grade gliomas. Neurosurg Focus 38: E2, 2015.

98 Wesseling P, van den Bent $\mathrm{M}$ and Perry A: Oligodendroglioma: pathology, molecular mechanisms and markers. Acta Neuropathol 129: 809-827, 2015.

99 Fontanilla HP, Pinnix CC, Ketonen LM, Woo SY, Vats TS, Rytting ME, Wolff JE and Mahajan A: Palliative reirradiation for progressive diffuse intrinsic pontine glioma. Am J Clin Oncol 35: 51-57, 2012.

Received August 18, 2016

Revised August 28, 2016

Accepted August 29, 2016 